\title{
Developing Housing Finance in Pakistan - Challenges and Opportunities
}

\section{Jamshed Uppal*}

\begin{abstract}
Expanding home-ownership poses a fundament financial challenge arising out of the long-term nature of the asset, which calls for the development of institutions and markets to facilitate the flow of long-term funds. Development of the secondary mortgage market would alleviate classical maturity mismatch and liquidity issues. The public sector can provide an enabling environment with sound macroeconomic policies, corporate governance, rule of law, and enforceability of contracts. This study draws policy implications using the empirical evidence on the determinants of mortgage depth and penetration across countries. A large part of the variation in these two dimensions across countries is explained by the level of their financial development. Development of long-term sources of funds intermediated through specialized institutions seems particularly important, as we find that the development of pension funds, which are a source of long-term funding, is strongly associated with mortgage market development. Monetary and macro-economic stability, as indicated by a low and stable rate of inflation, appears to be a strong predictor of mortgage market development. We also detect a positive relationship between the degree of competition in the financial sector and mortgage market development.
\end{abstract}

Keywords: House financing, mortgage markets, securitization, affordable housing, Pakistan.

JEL classification: G21, G28, G50.

\section{Introduction and Background}

Pakistan, like many other developing countries, faces an acute shortage of affordable housing. According to the World Bank, "the estimated housing shortage in Pakistan is up to 10 million units, of which about 40 percent is in urban areas." A critical dimension of the problem is the availability of housing finance which is "particularly low, with a mortgage-finance-to-GDP ratio of 0.25 percent-one of the lowest in South

\footnotetext{
${ }^{*}$ Catholic University of America, Washington DC.
} 
Asia (3.4 percent regional average; 3 percent in Bangladesh and 11 percent in India)," (World Bank, 2018).

Over time, the country has initiated a number of programs and built up institutions and a regulatory framework to address the problem, the latest being the PTI government's initiative Naya Pakistan Housing Program with the ambitious goal of building five million homes, and the creation of Pakistan Mortgage Refinance Company (PMRC). However, providing housing for low income families has remained an intractable challenge, as the root causes of the problem have remained unattended (see Said, 2016, and Rashid, 2019).

This study examines the underlying fundamental financial issues in expanding affordable housing. We also present a survey of the empirical evidence on the factors which may be contributing to the depth and breadth of the mortgage market. The reason for this approach is that innovative solutions across the globe can be instructive for Pakistan in tackling this problem. We also use our results to present policy recommendations.

The study is organized as follows. The next section briefly surveys the linkages between the housing sector and economic development. The following section discusses the role of housing finance as critical to home ownership on the demand side, and the role of construction of new homes and the real estate development on the supply side. This is followed by a brief survey on the state of housing and house financing in Pakistan. Characteristics of housing finance instruments and intermediation challenges are discussed next. We then present a short survey of the empirical evidence on cross-country differences in mortgage finance. It is followed by an empirical exercise in exploring the roles of financial development in increasing the depth and penetration of housing financing in a cross-country sample. The last section presents a summary and conclusions and discusses implications for public policy in Pakistan.

\section{Housing Sector and Economic Development}

There is overwhelming evidence that housing directly impacts the economy and also has positive impacts on human welfare by improving standards of living and social inclusion (Doling et al, 2013). In recognition of the welfare aspects of housing, it is included in the Universal Declaration of Human Rights, and the Millennium Development Goals. 
Besides providing shelter, a home provides direct benefits to the homeowner. It is a space that families share and grow in. Poor housing is associated with overcrowding, poor protection from the elements, and inadequate access to water and sanitation, which in turn lead to poor health outcomes. Besides improved health conditions, decent housing contributes other benefits such as less stress and increased security, especially for children and women. Homeownership increases civic engagement and stability as it leads to the emergence of a property-owning society having a stake in the local community and the county. Owning a home also provides security in old age.

The housing sector also carries direct benefits to the economy: new housing construction and home improvements, as well as the related supporting services generate economic activity with a multiplier effect. There is direct generation of employment for professional, skilled, semiskilled, and unskilled labor. Home ownership provides support for microand small businesses by not only providing supporting infrastructure but also can be used as collateral to secure a loan.

Figure 1: Housing - Economic, Social and Political Aspects

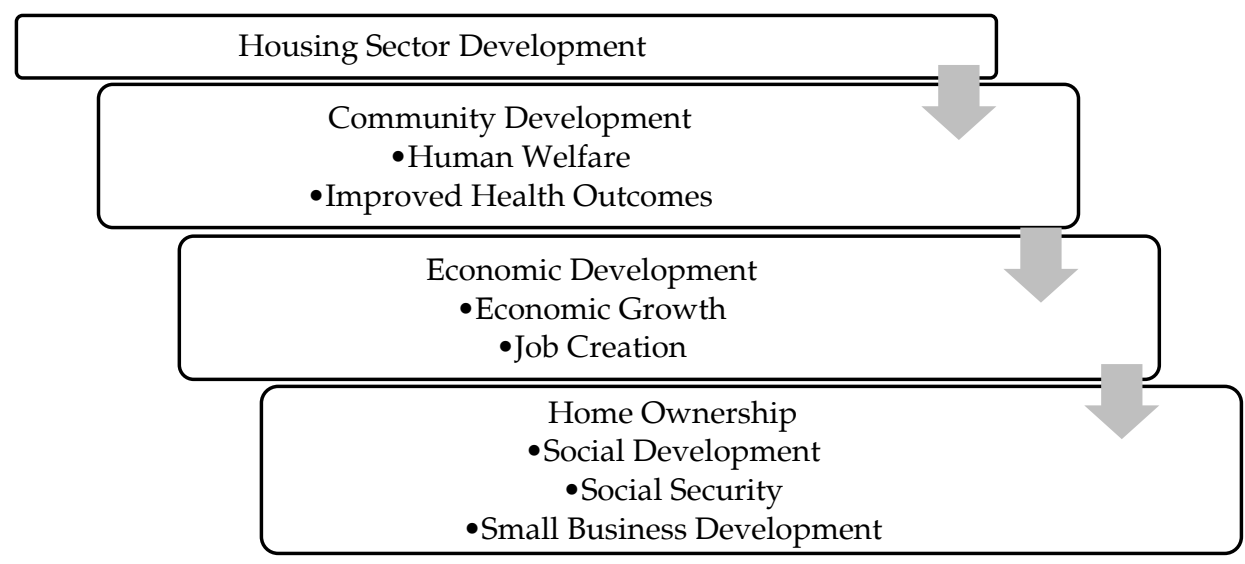

Source: Adapted from Doling et al. (2013).

Better housing also leads to improved health outcomes since it also implies better housing-related infrastructure such as water and sanitation. The link between the quality of housing and human health has long been acknowledged and has been documented since the time of industrialization in the West. The public response was in the form of various Public Health Acts which established standards for housing, sanitation, water supply, and sewerage. 
Healthier workers are more productive, which strengthens the economy. Better quality housing inculcates a sense of belonging and leads to community involvement for the general uplift of the quality of life by reducing stress. It creates civic sense and civic participation ${ }^{1}$. Home ownership has broader social impacts and positive social externalities. A widely held view, the ideal of a property-owning democracy, is that owning a home creates a stake in the country which leads to greater allegiance to the nation, and translates into increased political stability and greater motivation to work hard (Agus, 2002). Homeownership creates an incentive to build social capital because homeowners have a financial stake in their community.

Home ownership can also provide financial security later in life as the house can be used to generate income in old age, reducing old age poverty and thus promote economic and social stability. This aspect assumes special importance as pension systems are very limited in developing countries. The traditional old age security system is based on family and strengthened by religious or social norms. Home ownership in traditional societies allows the elderly to live rent-free in retirement, and substitute for having a pension plan (Ronald, 2008).

Residential construction carries positive impacts on the national output and employment. Nevertheless, construction output seems to have "a nonlinear, inverted U-shaped relationship with the stage of economic development," meaning that construction increases in economic importance up to a certain level of income and then declines at higher levels of income. The implication is that construction has a larger role to play in low- to middle-income economies.

Housing construction also generates employment including employment for technically skilled workers. The employment elasticity is higher in developing countries, which tend to employ more labor-intensive techniques. The economic impact of home ownership is further bolstered as the home provides a physical asset on which to build a small business, particularly important for women who may be house-bound. An owned property with secured property rights can be used as collateral to borrow funds for initiating home-based businesses.

1 "The links between poor housing and poor health are well established. Many, possibly hundreds, of cross-sectional studies have reported consistent and statistically significant associations between poor housing conditions and poor health," (Thomson and Pettigrew 2005, p. 5). 


\section{Housing and Finance}

The decision to build or purchase a home is principally driven by the family's ability to access financial funds. A house may be the single most expensive asset that the household would ever possess; the average price of a home is estimated to be around five times the household's annual income; therefore, owning a home necessitates access to a large amount of accumulated funds.

Housing finance, typically as a home mortgage from a specialized intermediary, allows investments in the home to be front-loaded in the expectation of income in the future. As such, housing finance is a critical component in the housing system and makes it possible for a much greater proportion of the population to become homeowners. Access to finance also has a key role to play in the construction industry, since builders and developers need to raise and invest large amounts before housing units can be sold or rented out.

Therefore, the inability to borrow and purchase a home frustrates many families' dream to own a home of their own. In developing countries, housing finance is limited to high earners with stable sources of income. The required down payment is large, typically greater than 30 percent and the borrowed amount is large relative to the value of the house. Families without access to mortgage loans are forced to save for many years, sometimes until retirement, or forced to abandon their dream of owning their own home.

Another indirect consequence of a lack of financial resources is that families are forced to build their home in incremental phases and homeimprovements, which may result in inefficient outcomes for the families as well as society. For example, people may start by using cheap, poor quality materials that soon need replacement (UN-Habitat, 2009).

Thus, the underdevelopment of mortgage markets constitutes a barrier to improving living conditions. By expanding the availability of housing finance, countries will directly expand housing for the population. Mortgages are financial instruments which allow home ownership much earlier in the life of the individual rather than at a belated stage or perhaps never.

Deepening of housing finance leads to an increase in housing supply and housing affordability, which has the potential to pull people out of 
slums. However, availability of mortgage finance is not a sufficient condition for expansion of affordable housing to the poor. In developing countries, the financial sector has consistently failed to deliver financial services to the poor and low income segments of society.

The development of housing finance not only helps in expanding home ownership, but also has a major impact on the development of the entire financial system.

Figure 2: Impacts of increasing penetration of housing finance

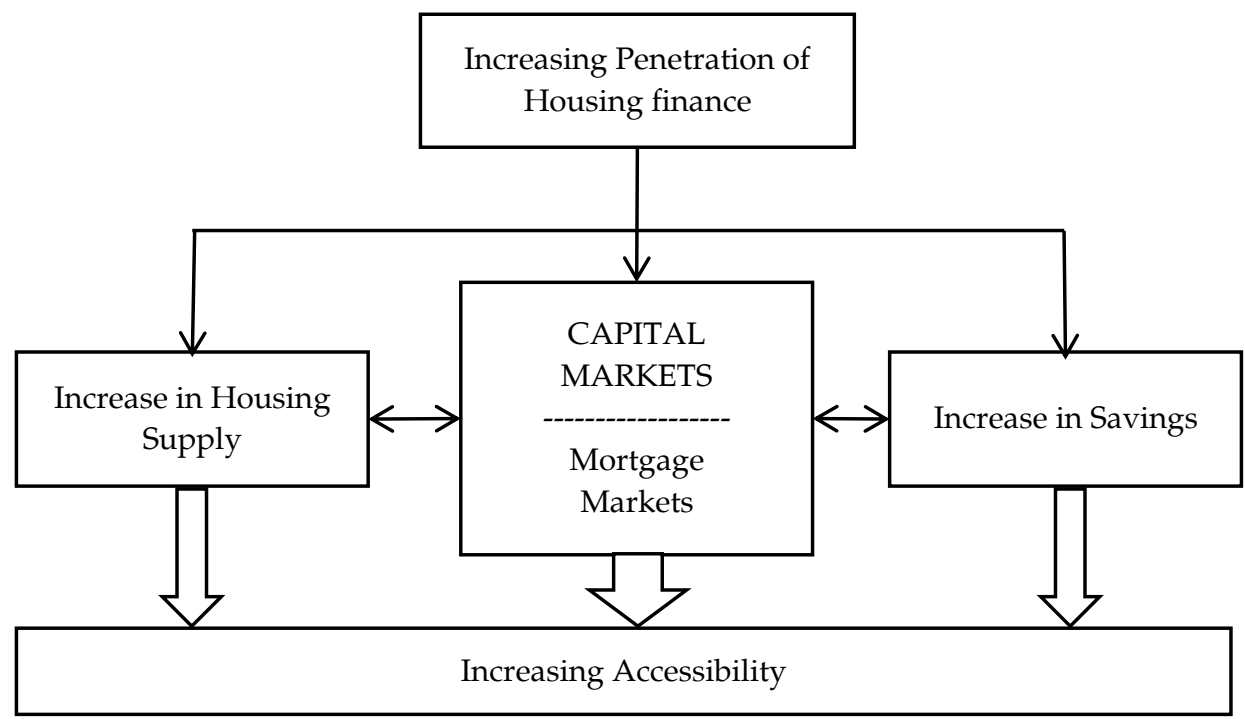

Source: Adapted from Doling et al. (2013).

Figure 2 depicts how the housing finance and the rest of the financial system are linked. Increasing the penetration of housing finance leads to capital market development, which increases savings in the economy. The mortgage markets develop within the wider capital markets. These concurrent developments in the economy and the financial sector expand access to housing finance to the households, allowing them to purchase housing in the present while paying for it in the future over the long term.

The size of the mortgage market is associated with the size and structure of the financial sector but is also related to economic fundamentals. However, the causal linkages are not unidirectional; the mortgage market is both dependent on the financial sector and economic growth and, in turn, it helps stimulate growth in the other sectors. First, 
mortgage market growth is supported by diverse and developed capital markets; on the other hand, capital markets are further strengthened and developed by the development of the mortgage markets. Second, mortgage market development stimulates household savings and leads to improvements in living conditions. ${ }^{2}$

\section{Housing Finance in Pakistan}

According to the World Bank, "the estimated housing shortage in Pakistan is up to 10 million units, of which about 40 percent is in urban areas." The acute housing shortage is likely to be further exacerbated as the urban population is estimated to be increasing at a rate of 2.3 million per year, which translates to additional requirement of about 360,000 households per year. Demographic trends, such as decreasing family size and a relatively younger population growing up to form new households, are likely to increase the demand for new housing. Thus the housing gap is likely to widen as the supply of new housing units will fall short of the demand arising from new households and the replacement of older units (World Bank, 2018).

The housing shortage will manifest itself as overcrowding, substandard housing, and expansion of slums. The existing state of affairs is already alarming, as around 47 percent of urban households are estimated to be living in katchi abadis. These are overcrowded informal settlements which lack basic infrastructure like schools, sanitation, and health services, contributing to poor social and economic outcomes.

Any strategy to alleviate the housing shortage must have housing finance as its central piece. This is where Pakistan seems to be particularly lagging behind other developing countries. In Pakistan the mortgagefinance-to-GDP ratio is only 0.25 percent which is the lowest in South Asia as can be seen in Figure 3.

\footnotetext{
${ }^{2}$ While these are important issues, these have not been research as much due to a lack of relevant, comparable data across countries, notably for developing countries.
} 
Figure 3: Home Mortgage Loans Outstanding (\% of GDP)

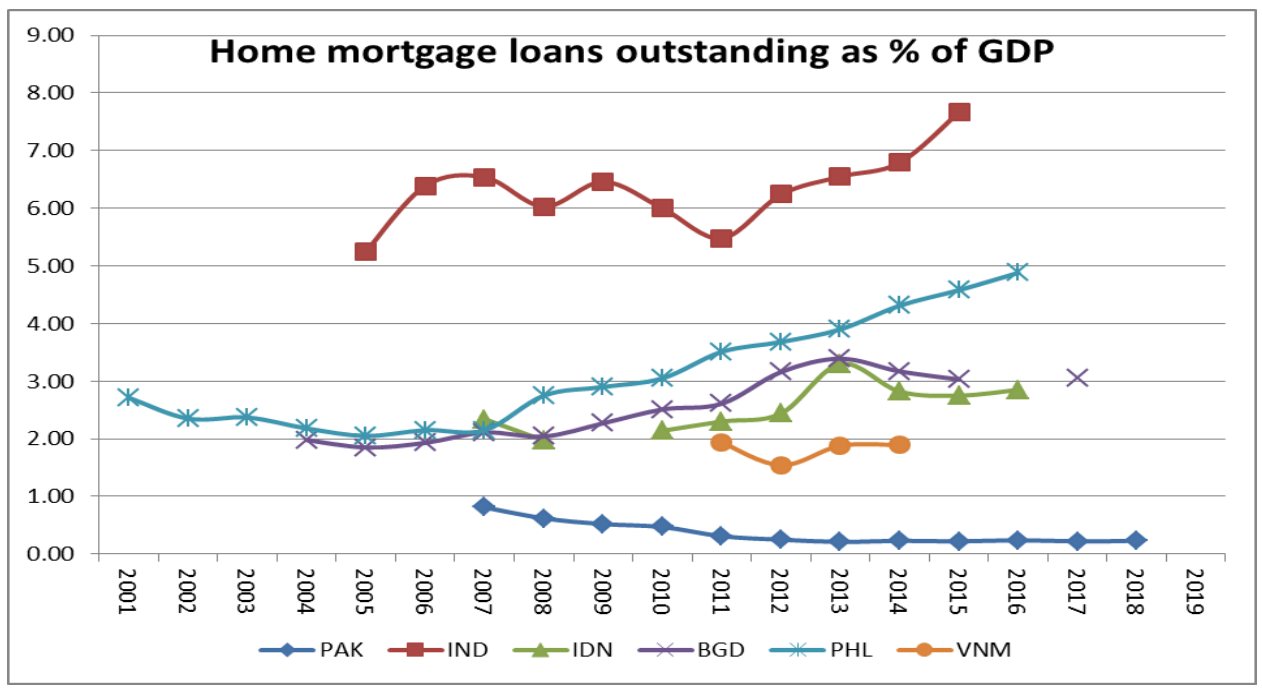

Source: HOFINET Database.

Typically housing finance is evaluated by researchers using two indicators: the depth and breadth of housing finance sectors. First, Mortgage Depth is indicated by the outstanding mortgage debt relative to GDP and focuses on the total size of the mortgage loans outstanding. ${ }^{3}$ The second measure, Housing Loan Penetration, gauges the percentage of the adult population with an outstanding loan used to purchase a home (Demirgüç-Kunt et al., 2018). ${ }^{4}$

Figure 3 plots the mortgage-finance-to-GDP ratio for Pakistan and a cohort of Asian countries. It is clear from the graph that Pakistan's mortgage finance ratio is at the bottom of the group. It is particularly notable that the ratio shows a declining trend while it has been increasing for the other countries. Overall access to financial services also remains limited, with fewer than 16 percent of adults having access to a formal accounts in 2014/15, so that the financial sector has a limited role in contributing to sustained and inclusive growth and dealing with the increasing housing shortage.

Figure 4 presents the housing loan penetration ratio as per three recent FINDEX surveys for Pakistan and a group of Asian countries. As

\footnotetext{
${ }^{3}$ Complied by the Housing Finance Information Network (HOFINET) from various sources.

${ }^{4}$ The Global Findex Database 2017: Measuring Financial Inclusion and the Fintech Revolution. World Bank: Washington, DC.
} 
can be seen the penetration ratio for Pakistan does not compare favorably with the cohort countries. Moreover, the ratio appears to have deteriorated over the three data points, in contrast with clear improvements for countries such as Bangladesh, Indonesia, India, and Thailand.

Figure 4: Outstanding housing loan (\% age 15+)

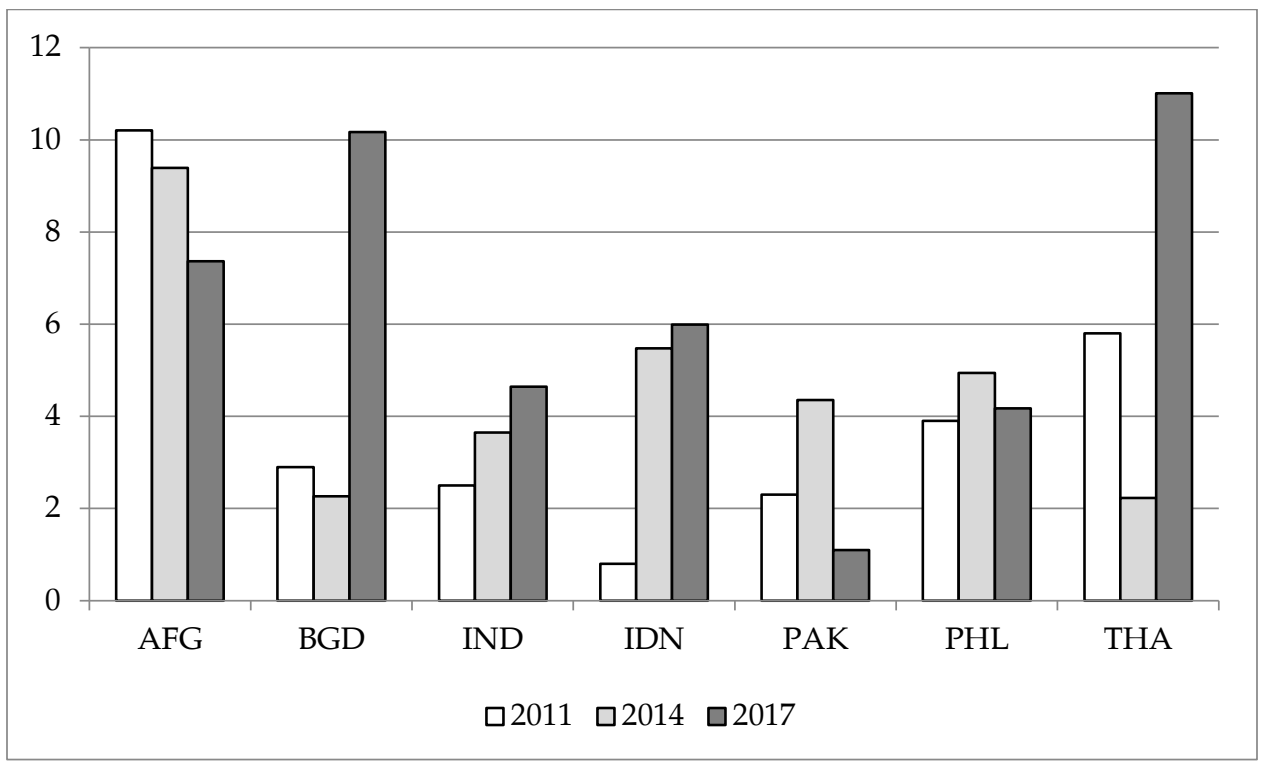

Source: FINDEX Database.

Another aspect of housing finance is the extent to which commercial banks make residential loans. Here, too Pakistan's banking sector lags behind the cohort countries. Figure 5 shows the residential and commercial loans as a percent of the total loans made by a group of Asian countries. We observe that only 2 percent of the total loans made by the Pakistani banks were residential, the lowest in the group, as compared, 9 percent residential loans by Indian banks, and 14 percent by Thai banks. Bangladesh banks also appear to be doing a better job with 3 percent of their total loans being residential. It is also notable that in contrast to housing loans, the Pakistan's banks seem to be fairly placed in making commercial loans. 
Figure 5: Residential \& Commercial Real Estate Loans to Total Loans, Percent

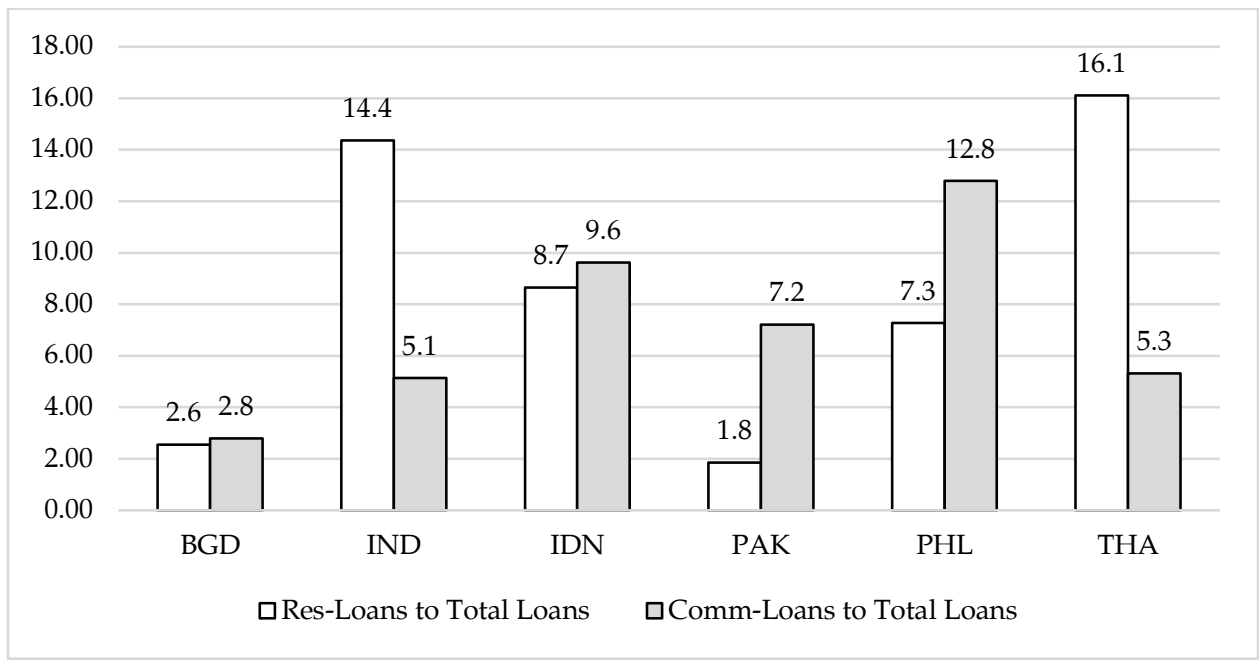

Source: HOFINET Database.

\section{Characteristics of Housing Finance}

A fundament financial challenge in house financing arises out of the long term nature of the asset which needs to be financed through longterm sources of finance, following a basic matching principle. Commercial banks are constrained in making long-term loans such as home mortgages since the prime sources of their funds are of a very short-term nature, mostly consisting of demand deposits. The banks thus face a fundamental dilemma in their maturity intermediation role. In order to contain their liquidity and interest rate risks, the banks tend to shy away from making mortgage loans, and when they do they tend to keep the mortgage tenure relatively short.

Historically, mortgage lending has been the province of institutions that can raise long-term funds to match the long-term nature of the assets, home loans. As early as the 18th century "building societies" sprang up in Europe to meet the challenge. Later, around the beginning of the $19^{\text {th }}$ century, cooperative societies and thrifts (saving banks/saving and loan associations) were created with the main focus on providing house financing. In the US the problem remained un-tackled until regulations adopted in the wake of the Great Depression (1929) that made it possible for banks to finance long-term mortgages. Creation of the secondary mortgage market (through Fannie Mae and later Freddy Mac) alleviated 
the classical maturity mismatch and liquidity issues. The securitization of the mortgages that followed brought down the cost of home financing significantly, and greatly expanded its availability. The provision of housing for low-income households has subsequently become tractable, due to the overall development of the housing finance market within the wider financial sector.

Creation of the secondary mortgage market can alleviate the classical maturity mismatch and liquidity issues. In Pakistan, the creation of the PMRC is with the same goal, although the development of the housing finance market within the wider financial sector development will likely remain a challenge.

Another challenge in house financing is the ubiquitous issue of informational asymmetry which is magnified in an environment rife with corruption and undocumented transactions. Lenders are hampered in the assessment of creditworthiness due to non-verifiability of borrowers' income and the value of the collateral, which render the traditional creditscoring models irrelevant and unusable.

Novel indicators, such as telecommunication records and payment histories from retailers and utilities, made possible due to the emergence of FinTech and Big Data, have been suggested to evaluate borrowers' creditworthiness. AI algorithms and big data analytics using social media activity and mobile phone usage can be used to identify, score, and underwrite credit to borrowers lacking a formal credit history. However, in order to realize the full potential of these alternative techniques, concerted efforts by the public authorities and the private financial industry would be needed to build an ecosystem in which new lending enterprises can emerge and develop.

A notable development has been the move away from public funded housing projects. To turn around a situation where "there is no money in building for the poor", the private sector is being incentivized to bring in the required capital, while the public sector provides tax and other subsidies. The profit motive also leads to the adoption of appropriate technologies and processes and to lower construction costs. Most importantly, the role of the public sector is to provide the enabling regulatory and legal environment. This includes sound macroeconomic policies, improving the governance environment, rule of law and enforceability of contracts, which are the prerequisites for the development of the financial sector. 


\section{Cross-Country Differences in Mortgage Finance - Empirical Evidence}

Researchers have noted a large variation in mortgage markets across countries, in both the depth and the degree of penetration. Warnock and Warnock (2008) note substantial variation with developed countries having large mortgage markets that are greater than 80 percent of their GDP, while in many emerging markets countries the mortgage markets are less than 10 percent of GDP and less than 1 percent of GDP across many low-income countries in Asia and Africa. Mortgage markets are strongly associated with the levels of GDP per capita, i.e., mortgage markets are a phenomenon of the high-income developed countries. Figure 6 captures this relationship, and depicts a strong association of the size of the mortgage loans with the per capita income across countries.

Figure 6: Mortgage Loans (\% of GDP) and GDP per Capita

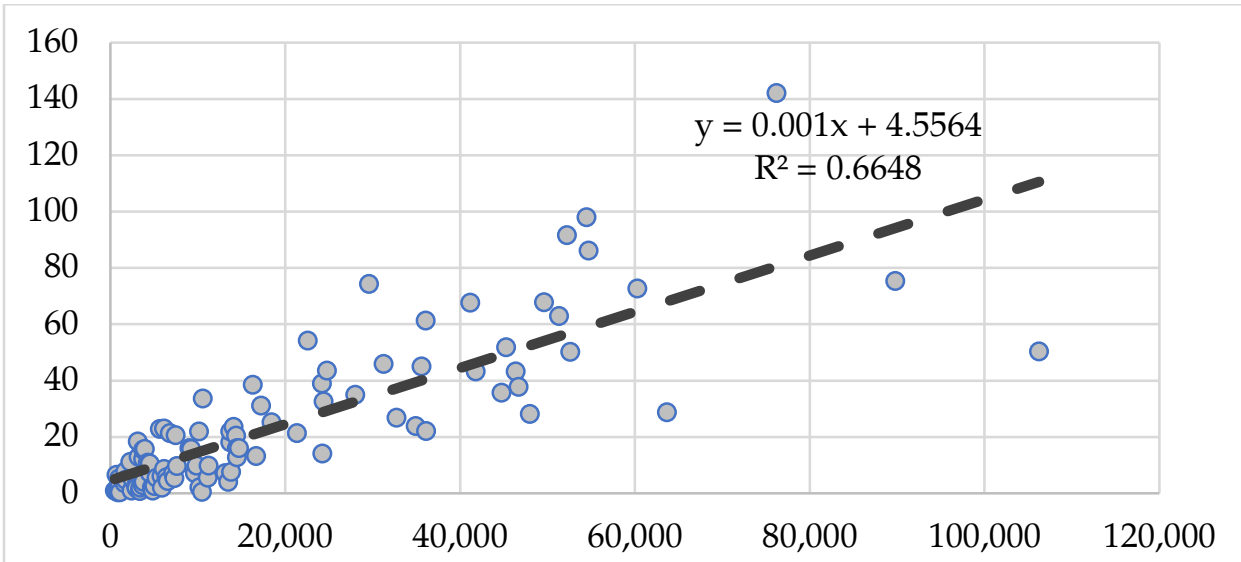

Source: HOFINET and FINDEX.

In developed economies, mortgage finance is widely available and is the preferred mode of financing home purchases. On the other hand, in low- and lower-middle-income countries the use of mortgage finance is very limited. Thus, on preliminary examination it may appear that "underdeveloped housing finance systems \{are\} just a symptom of the general shallowness of financial systems across developing countries" or, as Badev et al. (2014) suggest, housing finance is a "luxury" segment of the financial sector. This is supported by Beck et al. (2008) who show that capital markets and insurance sectors (long-term finance segments) develop at a later stage of economic development. 
However, Figure 6 also hints at a high degree of heterogeneity in the dependent variable, which underscores the fact that within countries, there are also wide variations in the depth and penetration of the mortgage instruments. Therefore, it is worthwhile to examine the country-level factors and policies that may help us to understand underdeveloped mortgage markets.

Another key factor in cross-country variation in the mortgage market development and in general in the overall financial development relates to the country's macroeconomic stability. An unstable financial environment is anathema to the development of financial instruments, especially long-term instruments. In one way economic instability is reflected in the rate of inflation experienced by a country. In view of the long-term nature of mortgage contracts, monetary stability would be a fundamental pre-requisite for developing mortgage markets.

We plot this relationship between the mortgage market depth and the average inflation rate across countries in Figure 7. The figure shows a non-linear negative relationship between average inflation (over the 2005$20 \mathrm{~d} 15$ period) and the mortgage depth as measured by mortgage loans as percentage of the country's GDP. The figure shows that high inflation is associated with shallow mortgage markets. However, we also observe a high degree of variation in mortgage depth across countries, which suggests that macroeconomic stability is a necessary but not sufficient condition for mortgage market development.

Figure 7: Mortgage Loans (\% of GDP) and Inflation

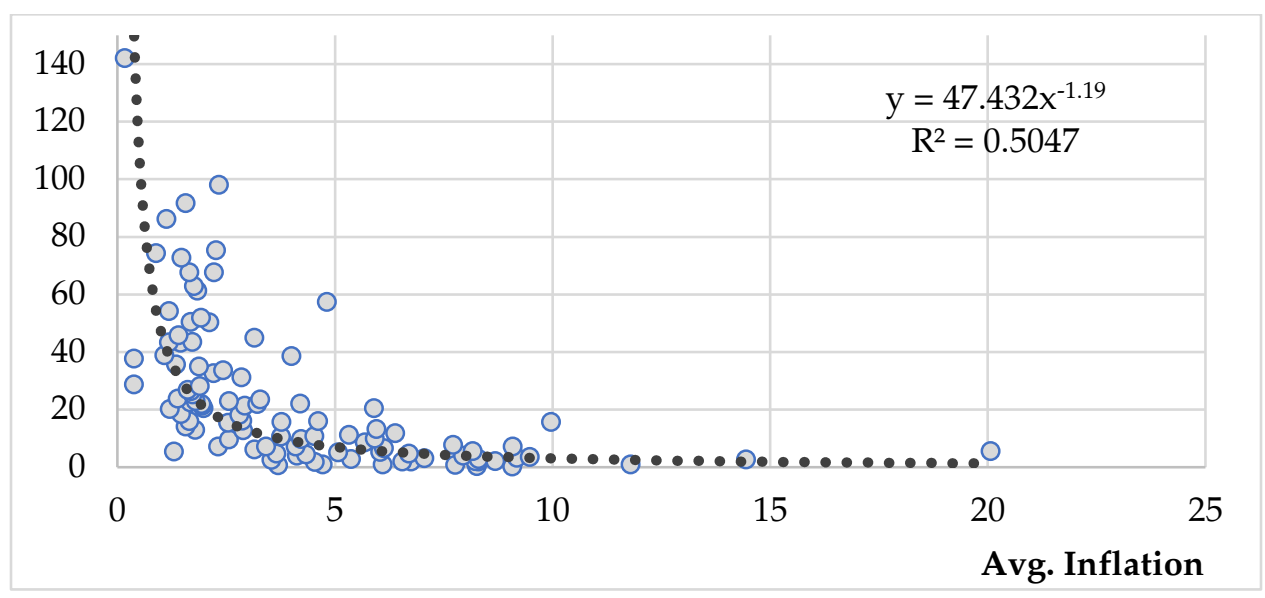

Source: HOFINET and FINDEX. 
Warnock and Warnock (2012) show that cross-country variation in mortgage size can be largely explained by differences in a few fundamental factors, such as the strength of legal rights for creditors and borrowers (mainly bankruptcy and collateral laws), the depth of credit information systems, the ease of registering property (as a proxy for how well the housing market works), and macroeconomic stability.

Badev et al. (2014) show a non-linear positive relationship between urbanization and mortgage depth and penetration. The authors conjecture that a higher share of urban population tends to increase both demand (due to higher mobility and smaller household size) and supply (due to lower delivery cost and more easily protectable creditor rights). However, there exists substantial variation in the depth and breadth of mortgage markets across countries, particularly within highly urbanized countries. Badev et al. (2014) also find evidence that the size of the insurance sector and the stock market, which can provide long-term financing, is strongly associated with mortgage market depth and penetration. On the other hand, government subsidies and support do not appear to be associated with greater mortgage depth and breadth.

Warnock and Warnock (2012) note that, for a variety of reasons, size (as measured by mortgage debt outstanding scaled by GDP) may not be an optimal measure to evaluate housing finance systems. The mortgage market in a country is influenced by housing price dynamics, and industry standards as to the allowable loan-to-value (LTV) ratios, and particularly prevalent tax treatments regarding mortgage loans. The mortgage markets are also affected by the credit conditions and terms allowable by the regulatory authorities.

\section{Further Empirical Evidence on Cross-Country Differences in Mortgage Finance}

The extant literature documents that the depth and breadth of mortgage markets is correlated with country-specific variables consistent with finance theory. In this section, we present further empirical evidence on the cross-country determinants of the depth and penetration of mortgage markets using more a recent and expanded data set. We thus extend the work of Warnock and Warnock (2012) and Badev et al. (2014), in order to explain country-specific factors that may account for such variations. 
Our first empirical exercise is to examine the relationship of mortgage depth and breadth to a country's financial development. For this, we use the World Bank's Financial Sector Development Indicators (FSDI) (World Bank, 2006). The FSDI database provides numerous variables spanning banking systems, capital markets, non-bank financial sectors, access to finance, and institutional environments. It presents the main dimensions of a financial sector in an overall index, the Financial Development Index, which is further split in to two main dimensions of the financial sector, i.e., the Financial Institutions Index and the Financial Markets Index. The Financial Institutions and Markets indices are grouped into three broad dimensions: (1) Access; (2) Depth; and (3) Efficiency. These indices are based on traditional measures, such as private credit to GDP ratios, stock market capitalization to GDP ratios, non-performing loans and banking spreads, but also include new indicators (collected via surveys), such as ease of access to a bank account by a household and ease of access to financing for a company. The benchmarking indices, combinations of ratios and synthetic statistics, allow one to tier countries in the same three dimensions (access, depth, efficiency).

Data from sources such as HOFINET, FINDEX, WDI, and FDSI were combined for the empirical analysis. In the first set of empirical tests, we run the following cross-country regressions:

Model A: Mortgage_Depth ${ }_{i}=\alpha_{i}+\beta_{1, i} G D P \_$percap $i+\beta_{2, i}$ AverageInflation $+\beta_{3, i}$ Index $j+\varepsilon_{i}$

Model B: Mortgage_Breadth ${ }_{i}=\alpha_{i}+\beta_{1, i} G D P \_$percap $i+\beta_{2, i}$ AverageInflation $+\beta_{3, i}$ Index $_{j}+\varepsilon_{i}$

In the empirical models the Index $x_{j}$ variable stands for the various indices

(j) as listed below, resulting in six different sub-models:

1. Base Model, does not include any index

2. Financial Development Index

3. Financial Institutions Index

4. Financial Markets Index

5. Financial Markets Access, Depth and Efficiency Indice

6. Financial Institutions Access, Depth, and Efficiency Indices.

The dependent variable in Model A is the Mortgage Loans as percent of GDP, a proxy for mortgage sector depth. In Model B the 
dependent variable is "Outstanding housing loan, older adults (\% age $25+)^{\prime \prime}$ from the Global FINDEX database, i.e., the percentage of respondents who report having an outstanding loan (by themselves or together with someone else) from a bank or another type of financial institution to purchase a home, an apartment, or land, older adults (\% age $25+)$. This indicator is a proxy for mortgage penetration or breadth.

In estimating these models, the White HeteroskedasticityConsistent Standard Errors and Covariance methods were employed.

The results of the estimation exercises are reported in Table 1 and 2. The base case, Model A1 in Table 1, establishes that the Mortgage Loans relative size depends on income per capita, i.e., that higher-income countries have greater Mortgage depth. This is consistent with the findings of Warnock and Warnock $(2008,2012)$ and Badev et al. (2014) that mortgage financing and markets emerge at a higher stage of economic development. The results in Table 2 also confirm the negative relationship between mortgage financing and inflation, underscoring the importance of monetary stability for the development of mortgage instruments. When Financial Development Indices are added to the regressions, as in Models $\mathrm{A} 2, \mathrm{~A} 3$ and A4, we see that each of the indices is statistically significant at $1 \%$ or better levels of significance. Thus the Financial Development indices bring additional explanatory power to the model beyond the per capita GDP and the rate of inflation. This is supported by increase in the value of the adjusted $\mathrm{R}^{2}$ and the Akaike and Schwarz information criteria. Therefore, it appears that mortgage finance is highly associated with financial development, controlling for the income level and rate of inflation. Examining the sub-indices we see that the Institutional Depth and the Market Depth seem to be dominant factors in explaining the influence of financial development on the mortgage depth.

Table 2 presents the results of empirical tests where outstanding housing loans by older adults is the dependent variable. Here, the average rate of inflation loses its explanatory power and the coefficients are statistically insignificant. Per capital income seems to be the dominant explanatory variable. Out of the Financial Development indices, only the Financial Markets index seems to be adding to the explanatory power beyond the per capita GDP. The Financial Institutional Depth index is significant at a $10 \%$ level of significance.

We next examine the relationship of mortgage depth, mortgage loans as percentage of GDP, to the structure of the financial sector. The 
structural variables are the total assets falling into each of the following categories, relative to the country's GDP (\% of GDP):

1. Mutual Funds

2. Nonbank Financial Institutions

3. Pension Funds

4. Portfolio Equity

5. Public Debt

6. Insurance Company Assets

7. Bank Deposits.

Nine cross-country regression models were run; in the base model only GDP per capita and the average inflation rate were included as explanatory variables. Model C2 includes all of the above structural variables. We include each of the structural variables in Models C3 through C9 along with per capital income and the inflation rate as independent variables. The results of these regressions are presented in Table 3.

The results for Model C2 indicate that the structural variables add to the explanatory power of the base model as indicated by the higher values of the adjusted $\mathrm{R}^{2}$ and the Akaike and Schwarz information criteria. We note that the coefficient on Pension Funds is positive and significant, but for Mutual Funds, Insurance Companies, and Bank Deposits the coefficients are insignificant, while for Nonbank Financial Institutions, Portfolio Equity, and Public Debt the coefficients are significant but negative. It seems that while Pension Funds have a positive influence on mortgage finance, the Nonbank Financial Institutions, Portfolio Equity, and Public Debt are negatively related to the mortgages.

Next we study the residential loans made by commercial banks; the dependent variable is the ratio (\%) of residential loans to the total loans outstanding in the banking sector. We examine how these are associated with the degree of competition, as measured by:

1. H-Statistic: A measure of the degree of competition in the banking market. It measures the elasticity of banks revenues relative to input prices. Under perfect competition, the $\mathrm{H}$-statistic equals 1. Under a monopoly, $\mathrm{H}$-statistic is less than or equal to 0 . 
2. Boone Indicator: A measure of degree of competition, calculated as the elasticity of profits to marginal costs. The more negative the Boone indicator, the higher the degree of competition is.

3. The Lerner index: The index ranges from a high of 1 to a low of 0 , with higher numbers implying greater market power.

We also include the ratio of non-performing loans as a possible explanatory variable to examine if higher default rates are influencing residential loans made by the banks.

The results of the cross-country regressions are placed in Table 4. The results (Models D1 through D5) indicate that the competition indicators have significant explanatory power beyond what is explained by the per capital income; the coefficients are statistically significant and of the predicted sign. Their explanatory power is the highest when considered together as in Model D1. When taken one at a time as in Models D2 through D4, the competition power variables retain statistical significance but the overall explanatory power of the models is reduced. It appears that higher degree of competition is associated with larger residential loans in the banks' portfolios. It is interesting to note that the coefficients on the Non-Performing Loans ratio variable are not significant. 
Table 1: Dependent Variable: Mortgage Loans percent of GDP

White Heteroskedasticity-Consistent Standard Errors \& Covariance

\begin{tabular}{|c|c|c|c|c|c|c|c|}
\hline & $\begin{array}{c}\text { MODEL } \\
\text { A1 } \\
\end{array}$ & $\begin{array}{c}\text { MODEL } \\
\text { A2 }\end{array}$ & & $\begin{array}{c}\text { MODEL } \\
\text { A3 } \\
\end{array}$ & $\begin{array}{c}\text { MODEL } \\
\text { A4 } \\
\end{array}$ & $\begin{array}{c}\text { MODEL } \\
\text { A5 } \\
\end{array}$ & $\begin{array}{c}\text { MODEL } \\
\text { A6 } \\
\end{array}$ \\
\hline Variable & Coefficient & Coefficien & & Coefficient & Coefficient & Coefficient & Coefficient \\
\hline GDP PER CAPITA & $\begin{array}{l}0.0010^{* * *} \\
(5.82)\end{array}$ & $\begin{array}{r}0.0006 \\
(3.36)\end{array}$ & $* * *$ & $\begin{array}{l}0.0006^{* * *} \\
(3.55)\end{array}$ & $\begin{array}{l}0.0007^{* * *} \\
(3.85)\end{array}$ & $\begin{array}{l}0.0005^{* * *} \\
(3.29)\end{array}$ & $\begin{array}{l}0.0007^{* * *} \\
(3.87)\end{array}$ \\
\hline AVG INFLATION & $\begin{array}{c}-0.3331 * \\
(-2.06)\end{array}$ & $\begin{array}{r}-0.1587 \\
(-1.69)\end{array}$ & * & $\begin{array}{c}-0.1231^{*} \\
(-2.15)\end{array}$ & $\begin{array}{r}-0.2351 \\
(-1.73)\end{array}$ & $\begin{array}{r}-0.1153 \\
(-1.73)\end{array}$ & $\begin{array}{c}-0.2647^{* *} \\
(-2.1)\end{array}$ \\
\hline $\begin{array}{l}\text { Financial } \\
\text { Development Index }\end{array}$ & & $\begin{array}{r}41.9828 \\
(3.68)\end{array}$ & $* * *$ & & & & \\
\hline $\begin{array}{l}\text { Financial Institutions } \\
\text { Index }\end{array}$ & & & & $\begin{array}{l}48.3921^{* * *} \\
\quad(4.26)\end{array}$ & & & \\
\hline $\begin{array}{l}\text { Financial Markets } \\
\text { Index }\end{array}$ & & & & & $\begin{array}{c}25.2405^{* * *} \\
(2.9)\end{array}$ & & \\
\hline Financial Institutions & & & & & & 3.2172 & \\
\hline Access Index & & & & & & $(0.54)$ & \\
\hline Financial Institutions & & & & & & $40.1528^{* * *}$ & \\
\hline Depth Index & & & & & & $(4.74)$ & \\
\hline Financial Institutions & & & & & & 7.9045 & \\
\hline Efficiency Index & & & & & & $(0.77)$ & \\
\hline Financial Markets & & & & & & & -3.4615 \\
\hline Access Index & & & & & & & $(-0.4)$ \\
\hline Financial Markets & & & & & & & $38.2395^{* * *}$ \\
\hline Depth Index & & & & & & & $(4.66)$ \\
\hline Financial Markets & & & & & & & 2.6614 \\
\hline Efficiency Index & & & & & & & $(-1.26)$ \\
\hline Constant & $\begin{array}{l}6.9376^{* *} \\
(2.61) \\
\end{array}$ & $\begin{array}{r}-5.7134 \\
(-1.92) \\
\end{array}$ & * & $\begin{array}{c}-14.6169 * * * \\
(-3.31) \\
\end{array}$ & $\begin{array}{r}3.1310 \\
(1.63) \\
\end{array}$ & $\begin{array}{r}-9.0942 \\
(-1.45) \\
\end{array}$ & $\begin{array}{r}2.6614 \\
(1.38) \\
\end{array}$ \\
\hline Adjusted R-squared & 0.6646 & 0.7161 & & 0.7170 & 0.6974 & 0.7474 & 0.7215 \\
\hline F-statistic & $97.0899 * * *$ & 82.5759 & $* * *$ & $82.9080 * * *$ & $75.5210^{* * *}$ & $58.3990 * * *$ & $51.2620 * * *$ \\
\hline Akaike info criterion & 8.2909 & 8.1337 & & 8.1308 & 8.1977 & 8.0364 & 8.1340 \\
\hline Schwarz criterion & 8.3700 & 8.2393 & & 8.2363 & 8.3032 & 8.1947 & 8.2922 \\
\hline Durbin-Watson stat & 2.1293 & 2.1853 & & 2.1882 & 2.1567 & 2.2202 & 2.0624 \\
\hline $\begin{array}{l}\text { Included } \\
\text { observations: }\end{array}$ & 98 & 98 & & 98 & 98 & 98 & 98 \\
\hline
\end{tabular}

Note: Cross-sectional regressions are estimated with 2015 dependent variable as a function of averaged regressors over the $2011-2015$ period. T-statistics are presented in parenthesis. ${ }^{* * *}$, ${ }^{* *}$, and ${ }^{*}$ indicate significance at the $1 \%, 5 \%$, and $10 \%$ levels, respectively. 
Table 2: Dependent Variable: Outstanding Housing Loan, Older Adults (\% age $25+$ )

\begin{tabular}{|c|c|c|c|c|c|c|}
\hline \multicolumn{7}{|c|}{ White Heteroskedasticity-Consistent Standard Errors \& Covariance } \\
\hline & $\begin{array}{l}\text { MODEL } \\
\text { B1 }\end{array}$ & $\begin{array}{l}\text { MODEL } \\
\text { B2 }\end{array}$ & $\begin{array}{l}\text { MODEL } \\
\text { B3 }\end{array}$ & $\begin{array}{l}\text { MODEL } \\
\text { B4 }\end{array}$ & $\begin{array}{l}\text { MODEL } \\
\text { B5 }\end{array}$ & $\begin{array}{l}\text { MODEL } \\
\text { B6 }\end{array}$ \\
\hline Variable & Coefficient & Coefficient & Coefficient & Coefficient & Coefficient & Coefficient \\
\hline GDP PER CAPITA & $\begin{array}{l}0.0004^{* * *} \\
(8.13)\end{array}$ & $\begin{array}{l}0.0003^{* * *} \\
(5.53)\end{array}$ & $\begin{array}{l}0.0004^{* * *} \\
(6.85)\end{array}$ & $\begin{array}{l}0.0003^{* * *} \\
(5.44)\end{array}$ & $\begin{array}{l}0.0003^{* * *} \\
(5.83)\end{array}$ & $\begin{array}{l}0.0003^{* * *} \\
(4.13)\end{array}$ \\
\hline AVG INFLATION & $\begin{array}{r}0.1178 \\
(0.83)\end{array}$ & $\begin{array}{r}0.1649 \\
(1)\end{array}$ & $\begin{array}{r}0.1302 \\
(0.84)\end{array}$ & $\begin{array}{r}0.1642 \\
(1.06)\end{array}$ & $\begin{array}{r}0.1313 \\
(0.83)\end{array}$ & $\begin{array}{r}0.1619 \\
(1.01)\end{array}$ \\
\hline $\begin{array}{l}\text { Financial Development } \\
\text { Index }\end{array}$ & & $\begin{array}{r}11.1891 \\
(1.54)\end{array}$ & & & & \\
\hline $\begin{array}{l}\text { Financial Institutions } \\
\text { Index }\end{array}$ & & & $\begin{array}{r}2.9020 \\
(0.34)\end{array}$ & & & \\
\hline Financial Markets Index & & & & $\begin{array}{l}11.4719 * * \\
(2.22)\end{array}$ & & \\
\hline $\begin{array}{l}\text { Financial Institutions } \\
\text { Access Index }\end{array}$ & & & & & $\begin{array}{r}-4.5079 \\
(-0.93)\end{array}$ & \\
\hline $\begin{array}{l}\text { Financial Institutions } \\
\text { Depth Index }\end{array}$ & & & & & $\begin{array}{c}10.8991 \text { * } \\
(1.97)\end{array}$ & \\
\hline $\begin{array}{l}\text { Financial Institutions } \\
\text { Efficiency Index }\end{array}$ & & & & & $\begin{array}{r}43.8854 \\
(-0.57)\end{array}$ & \\
\hline $\begin{array}{l}\text { Financial Markets } \\
\text { Access Index }\end{array}$ & & & & & & $\begin{array}{r}1.3190 \\
(0.23)\end{array}$ \\
\hline $\begin{array}{l}\text { Financial Markets } \\
\text { Depth Index }\end{array}$ & & & & & & $\begin{array}{r}9.3704 \\
(1.32)\end{array}$ \\
\hline $\begin{array}{l}\text { Financial Markets } \\
\text { Efficiency Index }\end{array}$ & & & & & & $\begin{array}{r}0.8805 \\
(0.18)\end{array}$ \\
\hline Constant & $\begin{array}{l}41.0242 * * * \\
(23.14)\end{array}$ & $\begin{array}{l}37.7076^{* * *} \\
(11.9)\end{array}$ & $\begin{array}{l}39.7762 * * * \\
(8.82)\end{array}$ & $\begin{array}{l}39.2293^{* * *} \\
(18.77)\end{array}$ & $\begin{array}{l}0.0000^{* * *} \\
(6.11)\end{array}$ & $\begin{array}{l}39.1654^{* * *} \\
(18.49)\end{array}$ \\
\hline Adjusted R-squared & 0.3294 & 0.3361 & 0.3230 & 0.3474 & 0.3296 & 0.3365 \\
\hline F-statistic & $24.5824 * *$ & $17.2023 * *$ & $16.2666^{* *}$ & $18.0378^{* *}$ & $10.4398 * *$ & 10.7355 \\
\hline Akaike info criterion & 7.7482 & 7.7481 & 7.7678 & 7.7310 & 7.7774 & 7.7672 \\
\hline Schwarz criterion & 7.8279 & 7.8543 & 7.8739 & 7.8371 & 7.9367 & 7.9264 \\
\hline Durbin-Watson stat & 1.8827 & 1.9027 & 1.8835 & 1.9207 & 1.9113 & 1.9204 \\
\hline Included observations: & 97 & 97 & 97 & 97 & 97 & 97 \\
\hline
\end{tabular}

Note: Cross-sectional regressions are estimated with 2015 dependent variable as a function of averaged regressors over the 2011-2015 period. T-statistics are presented in parenthesis. ${ }^{* *}$, **, and ${ }^{*}$ indicate significance at the $1 \%, 5 \%$, and $10 \%$ levels, respectively. 


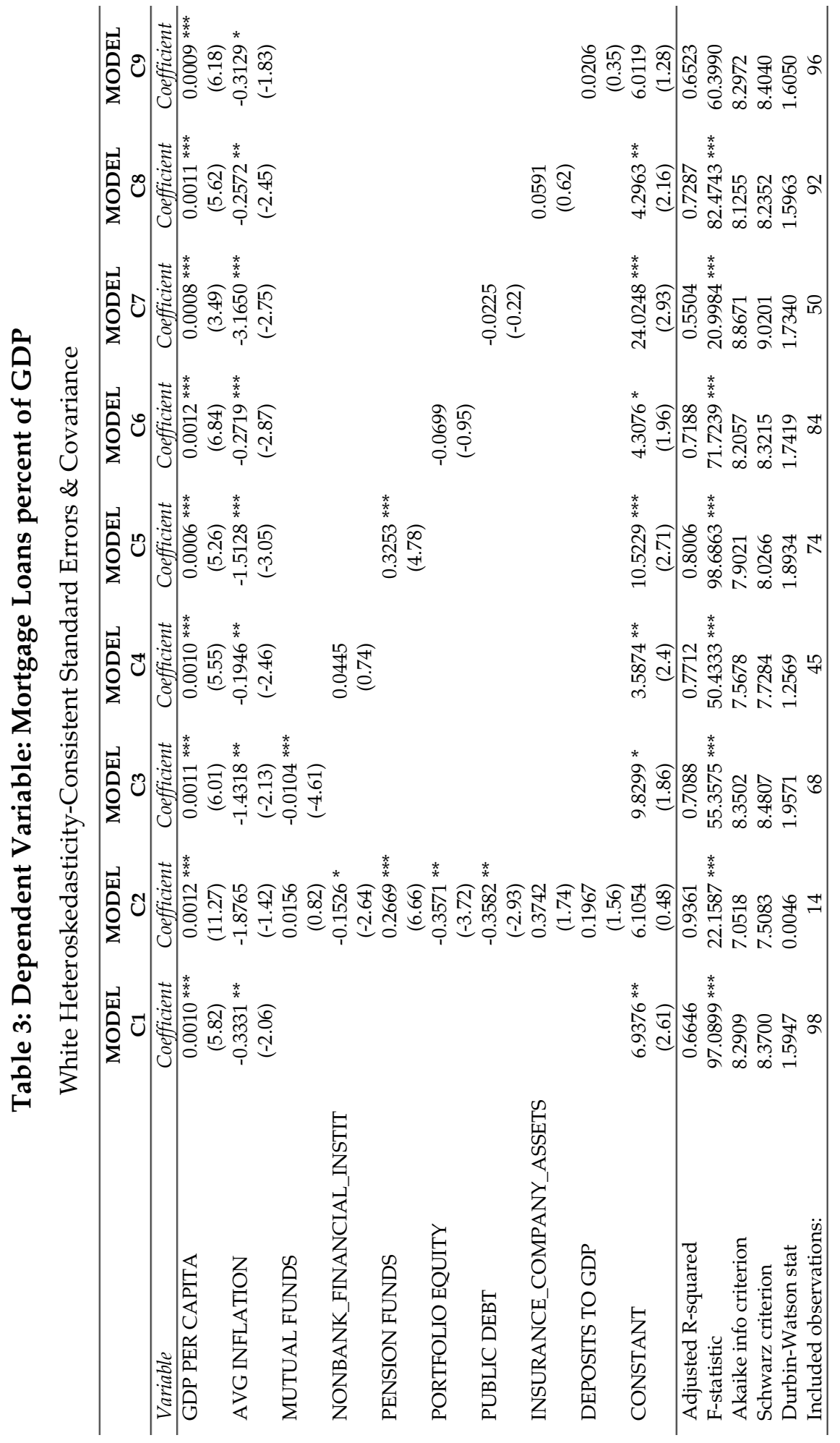


Table 4: Dependent Variable: Residential Loans to Total Loans

White Heteroskedasticity-Consistent Standard Errors \& Covariance

\begin{tabular}{|c|c|c|c|c|c|}
\hline & $\begin{array}{c}\text { MODEL } \\
\text { D1 }\end{array}$ & $\begin{array}{c}\text { MODEL } \\
\text { D2 }\end{array}$ & $\begin{array}{c}\text { MODEL } \\
\text { D3 }\end{array}$ & $\begin{array}{c}\text { MODEL } \\
\text { D4 }\end{array}$ & $\begin{array}{c}\text { MODEL } \\
\text { D5 }\end{array}$ \\
\hline Variable & Coefficient & Coefficient & Coefficient & Coefficient & Coefficient \\
\hline GDP PER CAPITA & $\begin{array}{l}0.0004^{* * * *} \\
(5.73)\end{array}$ & $\begin{array}{r}0.0000 \\
(0.88)\end{array}$ & $\begin{array}{r}0.0000 \\
(0.86)\end{array}$ & $\begin{array}{r}0.0000 \\
(0.64)\end{array}$ & $\begin{array}{l}0.0003^{* * *} \\
(2.91)\end{array}$ \\
\hline AVG INFLATION & $\begin{array}{r}-0.3754 \\
(-0.94)\end{array}$ & $\begin{array}{r}-0.1853 \\
(-1.44)\end{array}$ & $\begin{array}{r}-0.1688 \\
(-1.26)\end{array}$ & $\begin{array}{c}-0.2133 \text { * } \\
(-1.67)\end{array}$ & $\begin{array}{r}-0.4657 \\
(-1.13)\end{array}$ \\
\hline BOONE INDICATOR & $\begin{array}{c}0.7550 \text { *** } \\
(6.8) \\
-\end{array}$ & $0.0865^{* * *}$ & & & \\
\hline H_STATISTIC & $\begin{array}{c}13.7272 \text { ** } \\
(-2.32)\end{array}$ & & $-7.2087 * *$ & & \\
\hline LERNER INDEX & $\begin{array}{c}- \\
25.9323^{* * *} \\
(-3.01)\end{array}$ & & & $-5.9399 * *$ & \\
\hline NON_PERFORMING_LOANS & $\begin{array}{r}0.0588 \\
(0.42)\end{array}$ & & & & $\begin{array}{r}0.0091 \\
(0.06)\end{array}$ \\
\hline CONSTANT & $\begin{array}{c}22.5114^{* * *} \\
(4.33)\end{array}$ & $\begin{array}{l}4.7515^{* * *} \\
(3.75)\end{array}$ & $\begin{array}{c}9.0042^{* * *} \\
(3.8)\end{array}$ & $\begin{array}{l}6.7781 \text { *** } \\
(4.07)\end{array}$ & $\begin{array}{c}8.9538^{* * *} \\
(2.8)\end{array}$ \\
\hline Adjusted R-squared & 0.4342 & 0.0138 & 0.0580 & 0.0263 & 0.2739 \\
\hline F-statistic & $11.8730^{* * *}$ & 1.4789 & $2.9284^{* *}$ & 1.8725 & $13.0732 * * *$ \\
\hline Akaike info criterion & 7.6745 & 6.3882 & 6.3813 & 6.3891 & 7.8421 \\
\hline Schwarz criterion & 7.8742 & 6.4899 & 6.4889 & 6.4946 & 7.9483 \\
\hline Durbin-Watson stat & 2.1005 & 1.8446 & 1.8372 & 2.1067 & 2.0258 \\
\hline Included observations: & 86 & 104 & 95 & 98 & 97 \\
\hline
\end{tabular}

Note: Cross-sectional regressions are estimated with 2015 dependent variable as a function of averaged regressors over the 2011-2015 period. T-statistics are presented in parenthesis. ${ }^{* * *}$, ${ }^{* *}$, and ${ }^{*}$ indicate significance at the $1 \%, 5 \%$, and $10 \%$ levels, respectively.

\section{Summary and Conclusions}

This study adds to the empirical literature on mortgage depth and penetration across countries. A large part of the variation across both dimensions of mortgage market development is explained by the income levels in each country. Mortgage markets seem to emerge only at relatively high levels of incomes. This implies that economic development is a driver for the development of mortgage markets. Policies associated with financial system development should also advance mortgage market development.

At a more fundamental level, enforcement of contracts through effective rule of law and fidelity of property rights lies at the heart of 
financial development, which need to be ensured for the efficacy of longterm financial contracts such as a home mortgages. Financial development thrives on efficient flows of information and transparency to mitigate adverse selection and agency problems. Overall development of the financial system is dependent on a conducive legal and regulatory environment. For mortgage finance, the development of long-term sources of funds intermediated through specialized institutions is particularly important. We find that the development of pension funds, which are a source of such long-term funding, is strongly associated with mortgage market development.

Public policies geared towards expanding home ownership must incorporate strategies to foster financial development. Such policies should include ensuring monetary and macro-economic stability. Specifically, a low and stable rate of inflation appears to be a strong predictor of mortgage market development. We also detect a positive relationship between competition and mortgage market development, contrary to the finding by Badev et al (2014). Public policy, therefore, needs to ensure a fair degree of competition in the financial sector.

The empirical findings of our study are in line with the literature on policies to foster financial deepening. The strategy to expand affordable housing needs to have financial development as its cornerstone. Expanding homeownership and providing housing to the poor and at-risk families generates positive externalities for all. It is recognized that home ownership is the key to poverty alleviation, reduction of crime, and the building of wealth and civic society. 


\section{References}

Badev, A. I., Beck, T., Vado, L., \& Walley, S. C. (2014). Housing finance across countries: new data and analysis. World Bank policy research working paper, (6756).

Baer, T., Goland, T., \& Schiff, R. (2012). New credit-risk models for the unbanked.2013-04]. http://www.mckinsey.com/insights/risk _management/new_credit-risk_models_for_the_unbanked.

Bank for International Settlements, (2006). Housing Finance in the Global Financial Market. Committee on the Global Financial System, Papers No 26, Bank for International Settlements, Basel, Switzerland.

Black Olive Ventures (2014). Mortgage Market in India - the Real State of Estate. A monthly newsletter of Black Olive Ventures (BOV), 1.07, June.

Buckley, R.M. (1989). Housing finance in developing countries: a transaction cost approach. World Bank Publications, 347.

Buckley, R.M. (1994). Housing finance in developing countries: the role of credible contracts. Economic Development and Cultural Change, 42(2), 317-332.

Cerutti, E., Dagher, J., \& Dell'Ariccia, G. (2017). Housing finance and realestate booms: A cross-country perspective. Journal of Housing Economics, 38, 1-13.

Cheney, C., (2016). How Alternative Credit Scoring is Transforming Lending in the Developing World. Inside Development Financial inclusion, Devex.

Costa, A., Deb, A., \& Kubzansky, M. (2015). Big data, small credit: The digital revolution and its impact on emerging market consumers. Innovations: Technology, Governance, Globalization, 10(3-4), 49-80.

Demirguc-Kunt, A., Klapper, L., Singer, D., \& Ansar, S. (2018). The Global Findex Database 2017: Measuring financial inclusion and the fintech revolution. World Bank Publications. 
Doling, J., Vandenberg, P., \& Tolentino, J. (2013). Housing and housing finance-A review of the links to economic development and poverty reduction. Asian Development Bank Economics Working Paper Series, 362.

Habitat for Humanity (2018). The 2016-17 State of Housing Microfinance, 2017, Habitat for Humanity's Terwilliger Center for Innovation in Shelter, Atlanta, GA.

Household Integrated Income and Consumption Survey (HIICS), 2016. Household Integrated Income and Consumption Survey 2015-16, Islamabad.

Finance, H. (2011). Financial Stability-Back to Basics, $\|$ Global Financial Stability Report, Washington, DC. International Monetary Fund.

Okpala, D. C. (1994). Financing housing in developing countries: a review of the pitfalls and potentials in the development of formal housing finance systems. Urban Studies, 31(9), 1571-1586.

Rashid, A. (2019). Will PTI's housing programme address the root causes of the housing crisis? Dawn.

Said, M.A, (2016). Our Housing Crisis. Business Recorder - ePaper, World Economy and Business, 11.

Shahzad, M., and Farooq, M. (2014). The House Building Finance Corporation Limited Pakistan: A Sharia'h Appraisal of Ghar Aassn Flexi Scheme," SSRN Electronic Journal, DO - 10.2139/ssrn.2872557.

Ali, S. S., Shirazi, N. S., \& Zulkhibri, M. (2012). Challenges of affordable housing finance in IDB member countries using Islamic modes (Occasional Papers) (No. 254). The Islamic Research and Teaching Institute (IRTI).

Singh, C. (2013). Housing market in India: A Comparison with the US and Spain. IIM Bangalore Research Paper, (406).

Smets, P. (2019). Indian community-based housing finance systems: Potentials and pitfalls for urban development and housing improvement. International Journal of Urban Sciences, 23(4), 586-600.

State Bank of Pakistan, 2016, Half Yearly Housing Finance Review, Infrastructure, Housing \& SME Finance Department, Karachi. 
State Bank of Pakistan, (2019). Policy for Low Cost Housing Finance. State Bank of Pakistan, Government of Pakistan, Karachi.

State Bank of Pakistan, (2019). Mid-Year Performance Review of the Banking Sector. State Bank of Pakistan, Government of Pakistan, Karachi.

Sultana, R., Muntaha, S., Anisuzzaman, D. M., Sarker, F., \& Mamun, K. (2016). Automated Credit Scoring System for Financial Services in Developing Countries. In International Conference on Advanced Information and Communication Technology.

The World Bank (2006). Financial Sector Development Indicators Comprehensive Assessment through Enhanced Information Capacity, Washington, DC.

The World Bank, (2016). Housing Finance - World Bank Group Support for Housing Finance. An IEG Learning Product, International Bank for Reconstruction and Development.

The World Bank, (2018). Housing Finance in Pakistan to Become Accessible and Affordable. Press Release, Washington, DC, March 29, 2018.

The World Bank, (2018). Project Appraisal Document on a Proposed Credit in the Amount of SDR 99.6 Million US\$145 Million Equivalent to the Islamic Republic of Pakistan for a Pakistan Housing Finance Project. Report No: PAD2385 International Development Association, March 8, 2018.

UN-Habitat (2009). Guide to Preparing a Housing Finance Strategy. London: Earthscan.

Warnock, F.E., \& Warnock, V.C. (2012). Developing housing finance systems. In Reserve Bank of Australia Annual Conference, 16.

Warnock, V.C., \& Warnock, F.E. (2008). Markets and housing finance. Journal of Housing economics, 17(3), 239-251.

World Economic Forum, (2019). Making Affordable Housing a Reality in Cities. Insight Report, Cities, Urban Development $\mathcal{E}$ Urban Services Platform, in collaboration with PwC. 